\title{
The impact of the addition of iodoform on the physicochemical properties of an epoxy-based endodontic sealer
}

\author{
Milton Carlos KUGA ${ }^{1}$, Gisele FARIA ${ }^{1}$, Marcus Vinicius SÓ ${ }^{2}$, Kátia Cristina KEINE¹, Alailson Domingos dos SANTOS ${ }^{3}$, \\ Marco Antônio Húngaro DUARTE ${ }^{4}$, Patrícia Maria Poli KOPPER ${ }^{2}$
}

\author{
1- Department of Restorative Dentistry, Dental School, Univ. Estadual Paulista - UNESP, Araraquara, SP, Brazil. \\ 2- Department of Conservative Dentistry, Dental School, Federal University of Rio Grande do Sul, Porto Alegre, RS, Brazil. \\ 3- Department of Dental Materials, Dental School, Municipal Foundation of Education and Culture, Santa Fé do Sul, SP, Brazil. \\ 4- Department of Operative Dentistry, Endodontics and Dental Materials, Bauru School of Dentistry, University of São Paulo, Bauru, SP, Brazil.
}

Corresponding address: Patrícia Maria Poli Kopper - R. Pinheiros, n.14 - cond. Cantegril 2 - Viamão - RS - $94460-200$ - Brazil - Phone: 555133085191 e-mail: pkopper@terra.com.br

Submitted: January 11, 2013 - Modification: September 20, 2013 - Accepted: December 17, 2013

\section{ABSTRACT}

\begin{abstract}
ue to the low radiopacity of Sealer 26 , iodoform is frequently empirically added to this sealer. Thus, the interference of this procedure with the physicochemical properties of Sealer 26 must be evaluated. Objective: This study evaluated the influence of the addition of iodoform on setting time, flow, solubility, $\mathrm{pH}$, and calcium release of an epoxy-based sealer. Material and Methods: The control group was pure Sealer 26, and the experimental groups were Sealer 26 added with $1.1 \mathrm{~g}, 0.55 \mathrm{~g}$ or $0.275 \mathrm{~g}$ of iodoform. Setting time evaluation was performed in accordance with the ASTM C266-03 specification. The analysis of flow and solubility was in accordance with the ISO 6876-2001 specification. For the evaluation of $\mathrm{pH}$ and calcium ion release, polyethylene tubes were filled with the materials and immersed in flasks with $10 \mathrm{ml}$ of deionized water. After $24 \mathrm{~h}, 7,14,21,28$, and 45 days $\mathrm{pH}$ was measured. In 45 days, the calcium released was evaluated with an atomic absorption spectrophotometer. Results: The addition of iodoform increased setting time in comparison with pure sealer $(\mathrm{P}<0.05)$. As for flow, solubility, and calcium release, the mixtures presented results similar to pure sealer $(p>0.05)$. In the $24 \mathrm{~h}$ period, the mixture with $1.1 \mathrm{~g}$ and $0.55 \mathrm{~g}$ of iodoform showed lower $\mathrm{pH}$ than pure sealer and than sealer added with $0.275 \mathrm{~g}$ of iodoform $(\mathrm{P}<0.05)$. Conclusions: The iodoform added to Sealer 26 interferes with its setting time and solubility properties. Further studies are needed to address the clinical significance of this interference.
\end{abstract}

Keywords: Endodontics. Root canal filling materials. Physical and chemical properties.

\section{INTRODUCTION}

Endodontic sealers should have an antimicrobial activity ${ }^{28}$ and the capacity to stimulate the healing of periapical tissue ${ }^{19}$. These properties are related to the release of hydroxyl and calcium ions ${ }^{13}$ and the increase of $\mathrm{pH}^{15}$. Furthermore, endodontic sealers should have adequate flow, setting time and low solubility?.

In Brazil, the epoxy-based sealer Sealer 26 is one of the most used in root canal filling and is widely commercially available ${ }^{6}$. However, its radiopacity is lower than that of other endodontic sealers such as the methacrylate- based (Epiphany) ${ }^{16}$, gutta-percha point ${ }^{5}$ or even another epoxy-based (AH Plus) ${ }^{25}$. This difference of radiopacity may be inadvertently interpreted as failure in root canal filling.

A way to improve the radiopacity of Sealer 26 is to add iodoform, in a minimum ratio of $1: 3$, to the total volume of the sealer ${ }^{14}$. Materials containing iodoform have been suggested for root canal filling in primary teeth ${ }^{8}$. When added to Sealapex, the histological results do not change in relation to pure Sealapex ${ }^{17}$, and the mixture presented clinical applicability as an alternative radiopacifier for endodontic procedures.

Iodoform $\left(\mathrm{CHI}_{3}\right)$ is commonly used as 
radiopacifier for primary tooth root canal filling ${ }^{8,22,23,}$ but its use in Endodontics is controversial because of its potential for causing toxic effects ${ }^{4,23}$. Iodoform has a radiopacifying action similar to bismuth subnitrate and higher than zinc oxide, barium sulfate, zirconium oxide, and calcium tungstate ${ }^{10}$.

Due to the radiopacity of Sealer 26, endodontists have empirically added iodoform to this sealer. But there are no studies evaluating the interference of this procedure with the physicochemical properties of Sealer 26. Since some essential properties such as solubility and setting time depend on the powder/resin ratio of a sealer, preparing the material with varying consistency may result in variations in the properties of the sealer ${ }^{7}$. This may have a clinical consequence, such as difficulty in handling and/or interference in the antimicrobial action 7,20 .

Flow is important as it determines the ability of the sealer to penetrate into small irregularities, ramifications and lateral canals ${ }^{1}$. When the flow of the sealer is not in accordance with ISO (6876) or ADA (57) norms, its use in root canal obturation is contraindicated. The preservation of alkalization potential and calcium ion release properties of the sealer after its manipulation are important to their biological and microbiological actions ${ }^{9}$.

Therefore, studies that assess the interference of the addition of several proportions of iodoform with the properties of Sealer 26 are necessary. This study aims to evaluate the hypothesis that the addition of iodoform interferes negatively with its physicochemical properties.

The aim of this study was to evaluate the initial and final setting time, flow, solubility, $\mathrm{pH}$ and calcium release from an epoxy-based sealer (Sealer 26), both pure and added with $1.1 \mathrm{~g} ; 0.55$ $\mathrm{g}$ or $0.275 \mathrm{~g}$ of iodoform.

\section{MATERIAL AND METHODS}

The epoxy-based sealer used for this study was Sealer 26 (Dentsply, Maillefer Instruments SA, Ballaigues, Switzerland). The main constituents of this material, according to the manufacturer, are: a. powder (bismuth trioxide, calcium hydroxide, hexamethylenetetramine, titanium dioxide); b. resin (Bisphenol-epoxy resin).

To manipulate Sealer 26, $1.1 \mathrm{~g}$ of powder was added to $1.0 \mathrm{~g}$ of resin and mixed during $30 \mathrm{~s}$. This mixture was considered as the control group (G1). For the experimental groups, the mixture was prepared by adding iodoform (Biodinâmica Ind. Com., Ibiporã, PR, Brazil) in proportions of $1.1 \mathrm{~g}$ (G2), $0.55 \mathrm{~g}$ (G3), and $0.275 \mathrm{~g}$ (G4).

\section{Determination of setting time}

The initial and final setting times of the mixtures were determined according to the International Standards Organization (ISO) 6876 specification ${ }^{18}$ and the ASTM C266-03 (Philadelphia: ASTM; 2008) specification ${ }^{2}$. All specimens were measured under controlled temperature and humidity: $37 \pm 1^{\circ} \mathrm{C}$ and $95 \pm 5 \%$ relative humidity. The sealers were mixed and inserted into metallic ring molds with $10 \mathrm{~mm}$ of diameter and $2 \mathrm{~mm}$ of thickness $(n=3$, each group).

At 180 seconds, each specimen was indented with a Gilmore needle (113.5 g) until the initial setting time was determined. Then, a Gilmore needle weighing $456.5 \mathrm{~g}$ was used to determine the final setting time. Setting times were determined as being the time elapsed from the beginning of the mixing to the time at which no indentation was detected on the surface of the mixtures. The initial and final setting times were determined when the Gilmore needles, with $113.5 \mathrm{~g}$ and 456.5 $\mathrm{g}$ respectively, failed to leave a definite mark on the surface of the sample. Data obtained was subjected to one-way ANOVA and Dunn tests, at a significance level of $5 \%$.

\section{Flow}

All procedures were performed according to ISO $6876: 2001^{1,7,18}$. The sealers were mixed according to the conditions described before, and $0.05 \pm 0.005$ $\mathrm{ml}$ of mixture was placed on the center of a glass plate with a graduated syringe. After $3 \mathrm{~min}, \mathrm{a}$ second plate weighing $20 \mathrm{~g}$ and a weight of $100 \mathrm{~g}$ were placed on the sealer. After seven additional minutes, the mean of the biggest and smallest diameter of the disc of sealer was recorded in $\mathrm{mm}$ using a digital caliper with a resolution of 0.01 mm (Mitutoyo MTI Corporation, Tokyo, Japan). The mean of three measurements for each sealer was taken as the flow of the material and the data submitted to Kruskal-Wallis test at a significance level of $5 \%$.

\section{Solubility}

Teflon ring molds ( $n=10$, each group) measuring $1.5 \mathrm{~mm}$ thickness and $20 \mathrm{~mm}$ internal diameter were filled with the mixtures. Two glass plates, covered with colorless cellophane, were placed under and on the mold. The samples were stored for 45 days in $37 \pm 1^{\circ} \mathrm{C}$ and $95 \pm 5 \%$ relative humidity to set. After the removal of residues or loose particles, the specimens were placed in a desiccator with silica for $24 \mathrm{~h}$. Then, they were weighed on a precision scale (Shimadzu AW-220; Shimadzu, São Paulo, SP, Brazil) and immersed individually in $50 \mathrm{ml}$ of deionized water in closed flasks. Special care was taken to keep the specimens hung in the water. All specimens 
were again stored for 7 days in $37 \pm 1^{\circ} \mathrm{C}$. After this period, the specimens were again placed in a desiccator for $24 \mathrm{~h}$ and subsequently weighed, in similar conditions as described above. The solubility and disintegration between the original mass of the specimen and its final mass were calculated to deduce the percentage of original mass loss of the specimen. All procedures were in accordance with Vivan, et al. ${ }^{27}$ (2010). The data obtained was submitted to Kruskal-Wallis test at a significance level of $5 \%$.

\section{pH and calcium release}

Forty polyethylene tubes measuring $0.5 \mathrm{~cm}$ in length and $1.0 \mathrm{~mm}$ in internal diameter $(n=10$, each group) were filled with the mixtures by using a Lentulo spiral (Dentsply, Maillefer Instruments SA, Ballaigues, Switzerland).

The tubes filled with fresh mixtures were weighed in order to check the standardization of the amount of sealer. They were placed in polypropylene flasks (Injeplast, São Paulo, SP, Brazil) containing $10 \mathrm{~mL}$ of deionized water and kept at $37^{\circ} \mathrm{C}$. Prior to immersion of the specimens, both $\mathrm{pH}$ and calcium concentration of the deionized water were verified, with $\mathrm{pH}$ being 6.8 and calcium being totally absent. Evaluations of $\mathrm{pH}$ and calcium ion release were carried out after $24 \mathrm{~h}$, $7,14,21,28$, and 45 days. The specimens were kept in the same distilled water during all the experiment. Measurement of $\mathrm{pH}$ was performed with a pHmeter (model Q400I; Quimis, Diadema, SP, Brazil), previously calibrated with solutions of known $\mathrm{pH}(4,7$, and 14), at constant temperature $\left(25^{\circ} \mathrm{C}\right)$. The flasks were placed in a shaker
(Farmen, São Paulo, SP, Brazil) for 5 seconds before $\mathrm{pH}$ measurement. The control procedure included measuring the $\mathrm{pH}$ of the water in which no specimens had been immersed.

In 45 days, a Spectra $55 \mathrm{~B}$ atomic spectrophotometer (Varian, Inc.,Palo Alto, CA, USA) was used to determine the calcium release concentration (in $\mathrm{ppm}$ ) in the deionized water. Lanthanum oxide was added to all samples to eliminate ionic interference. Solutions containing calcium concentrations of $0,1,2,3,4$ and 5 ppm were used to create a standard calibration curve ${ }^{23}$.

\section{RESULTS}

The initial and final setting times between the groups were statistically different $(P>0.05)$. The mean and standard deviation of the initial and final setting times in minutes for Sealer 26 and experimental mixtures are showed in Table 1.

Regarding the flow test, the experimental mixtures and the pure Sealer 26 presented similar results $(P>0.05)$ (Table 2$)$. The flow of all mixtures is in accordance with ISO 6876:2001 ${ }^{18}$.

The experimental groups presented higher solubility than Sealer $26(P<0.05)$, but no differences were observed between them $(P>0.05)$. All the sealers released calcium and were similar ( $P>0.05$ ) (Table 3).

The mean and standard deviation for $\mathrm{pH}$ values, in several periods, of Sealer 26 and the three experimental mixtures are presented in figure 1. In the $24 \mathrm{~h}$ period, the addition of $1.1 \mathrm{~g}$ (G2) or $0.55 \mathrm{~g} \mathrm{(G3)}$ of iodoform promoted reduction of $\mathrm{pH}$ values. In addition, these values were lower than

Table 1- Mean and standard deviation of the initial and final setting times in minutes for Sealer 26 and experimental mixtures

\begin{tabular}{ccccc}
\hline & G1 & G2 & G3 & G4 \\
& $(\mathbf{1 . 1 : 0 . 0 : 1 . 0 )}$ & $(\mathbf{1 . 1 : 1 . 1 : 1 . 0 )}$ & $\mathbf{( 1 . 1 : 0 . 5 5 : 1 . 0 )}$ & $\mathbf{( 1 . 1 : 0 . 2 7 5 : 1 . 0 )}$ \\
\hline Initial & $470(8.66)^{\mathrm{a}}$ & $11.486(0.1)^{\mathrm{b}}$ & $9.136(199)^{\mathrm{c}}$ & $5.595(0.1)^{\mathrm{d}}$ \\
\hline Final & $2.569(2.88)^{\mathrm{a}}$ & $15.536(0.1)^{\mathrm{b}}$ & $11.952(509)^{\mathrm{c}}$ & $7.675(103)^{\mathrm{d}}$ \\
\hline
\end{tabular}

$a, b, c, d$ Different letters in each line indicate significant difference $(P<0.05)$. The proportion is in the sequence powder:iodoform:resin (in weight)

Table 2- Mean and standard deviation of flow and calcium release for Sealer 26 and experimental mixtures

\begin{tabular}{ccccc}
\hline & G1 & G2 & G3 & G4 \\
& $(\mathbf{1 . 1 : 0 . 0 : 1 . 0 )}$ & $\mathbf{( 1 . 1 : 1 . 1 : 1 . 0 )}$ & $\mathbf{( 1 . 1 : 0 . 5 5 : 1 . 0 )}$ & $\mathbf{( 1 . 1 : 0 . 2 7 5 : 1 . 0 )}$ \\
\hline Flow $(\mathrm{mm})$ & $22.99( \pm 0.83)$ & $21.91( \pm 1.87)$ & $22.00( \pm 0.58)$ & $22.01( \pm 1.01)$ \\
Calcium release $(\mathrm{ppm})$ & $1.37( \pm 0.20)$ & $1.12( \pm 0.27)$ & $1.23( \pm 0.13)$ & $1.180(0.20)$ \\
\hline
\end{tabular}

* No statistical difference was observed between the groups $(P>0.05)$. The proportion is in the sequence powder:iodoform:resin (in weight) 
Table 3- Mean of percentage of original mass loss for Sealer 26 and experimental mixtures

\begin{tabular}{ccccc}
\hline & G1 & G2 & G3 & G4 \\
& $(1.1: 0.0: 1.0)$ & $(\mathbf{1 . 1 : 1 . 1 : 1 . 0 )}$ & $(\mathbf{1 . 1 : 0 . 5 5 : 1 . 0 )}$ & $\mathbf{( 1 . 1 : 0 . 2 7 5 : 1 . 0 )}$ \\
\hline Mass loss & $2.0^{\mathrm{a}}$ & $10.98^{\mathrm{b}}$ & $10.89^{\mathrm{b}}$ & $9.38^{\mathrm{b}}$ \\
\hline
\end{tabular}

a,b Different letters in each line indicate significant difference $(P<0.05)$. The proportion is in the sequence powder:iodoform:resin (in weight)

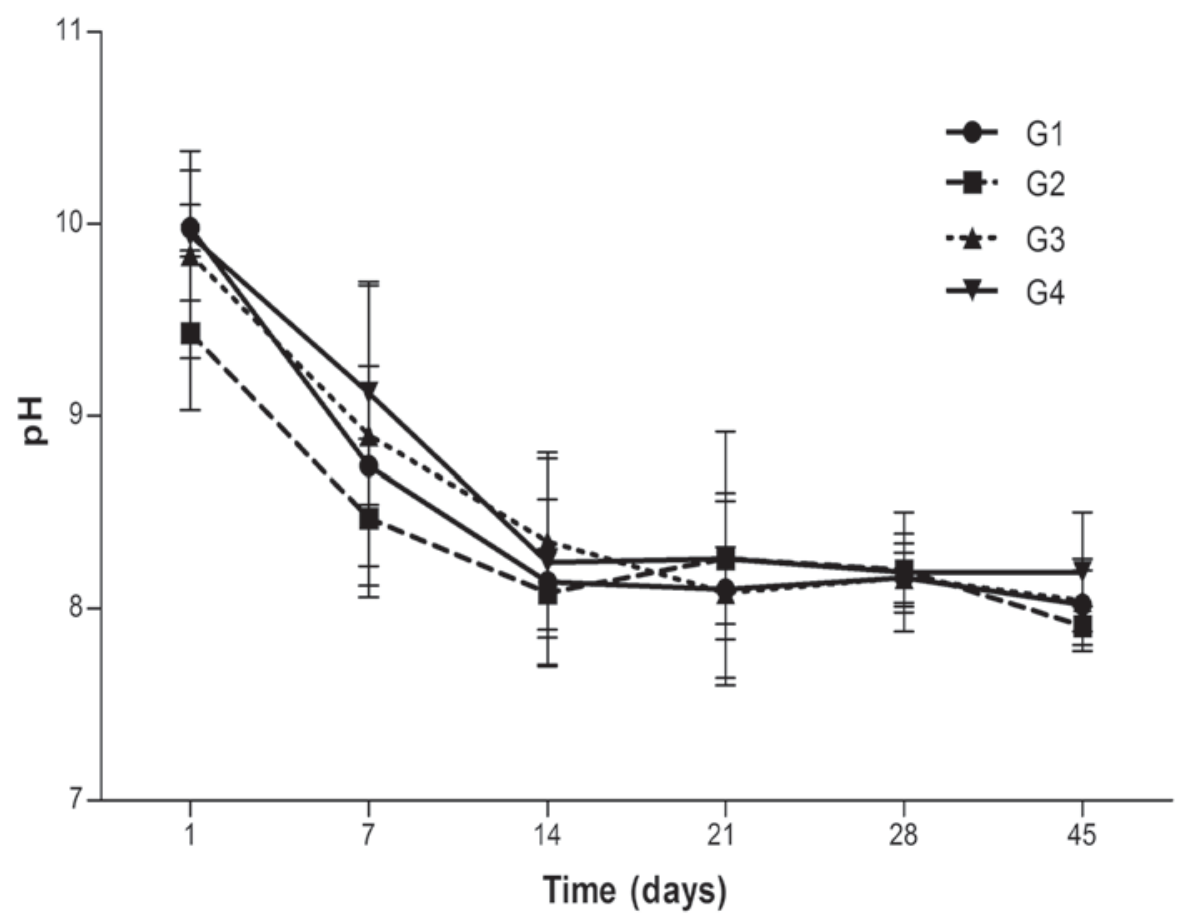

Figure 1- pH changes of Sealer 26 and mixtures according to different periods of time

the ones presented by $\mathrm{G} 1$ and $\mathrm{G} 4(\mathrm{P}<0.05)$. In the other periods, $\mathrm{pH}$ values between the groups were similar $(\mathrm{P}>0.05)$. The $\mathrm{pH}$ values reduced in the course of time.

\section{DISCUSSION}

Studies of the initial and the final setting time, flow, solubility, $\mathrm{pH}$ and calcium releases of the pastes and endodontic sealers are as important as the ones that evaluate antimicrobial activity ${ }^{3,20}$, radiopacity ${ }^{16,25}$ biological behavior ${ }^{23}$ and toxic effect $^{4}$ of these materials. The decision making for clinical use of these materials have to be based on these evidences.

The results of the present study, particularly of setting time and solubility tests, allow us to accept the hypothesis that the addition of iodoform, independently of the proportion added, interferes with the properties of Sealer 26. Therefore, this procedure should be avoided.

The addition of iodoform to the powder of the sealer in proportions of $1.1 \mathrm{~g}, 0.55 \mathrm{~g}$, and $0.275 \mathrm{~g}$ provides total mass increase of $52.38 \%, 26.19 \%$, and $13.09 \%$, respectively. Despite this, the flow was similar in all groups. When $10 \%$ calcium hydroxide was added to another epoxy-based sealer (AH Plus), the flow reduced significantly in comparison with the original consistency ${ }^{11}$. However, $\mathrm{AH}$ Plus is a paste/paste system and Sealer 26 is a powder/paste system and the amount, in volume, of iodoform aggregated was insufficient to promote alterations in the sealer flow.

Several studies reported the importance that endodontic sealers present alkaline $\mathrm{pH}$ value and promote calcium ion release ${ }^{9,15,21}$. In the 24 h period, the addition of iodoform to $G 2$ and $G 3$ groups promoted reduction of $\mathrm{pH}$ value probably because the amount of calcium hydroxide present in the powder sealer decreased in relation to the sealer original proportion $(0.37 \mathrm{~g} / \mathrm{g})$. In all the other periods, there was reduction of the $\mathrm{pH}$ values. However, in each of these periods, the values among different groups were similar. The presence of some acid hydrogen components in the sealer, such as bisphenol-epoxy resin, may have caused a reaction with hydroxyl ion causing $\mathrm{pH}$ decrease ${ }^{24}$. The setting reaction of the substances that compose the sealer, with the consequent 
prevention of hydroxyl ion release, may have also contributed to the prevention of hydroxyl ion release ${ }^{24}$.

In this study, the assessment of calcium release by the mixtures was only carried out at the end of the experiment and the values corresponded to the release throughout the experiment. It is possible that the same chemical reactions may have been involved, as partial neutralization of hydroxyl ions also occurred in the calcium chelation ${ }^{24}$. Other studies with Sealer 26 were conducted in different conditions, which makes the comparison with our results impossible ${ }^{9,26}$.

The addition of iodoform into sealer powder, in all proportions used, promoted increase of initial and final setting time. The setting of the sealer occurs because of the reaction between the bisphenolepoxy resin and hexamethylenetetramine ${ }^{9}$. The addition of iodoform decreased the amount of hexamethylenetetramine, significantly affecting the setting time of the sealer. Probably, as a consequence of the interference with setting time and of powder/resin ratio modification, the solubility of experimental mixtures increased when compared with the original Sealer 26 sealer. Similarly, when calcium hydroxide was added into AH Plus (epoxy-based sealer), there was an increase in the solubility of the seale ${ }^{11}$. The powder/liquid ratio influences the physicochemical properties of endodontic sealers ${ }^{7}$.

Thus, the addition of iodoform in Sealer 26 interferes with the physicochemical properties of the material. Other studies should be conducted to select a radiopacifier that does not interfere with the epoxy-based sealer properties.

\section{CONCLUSIONS}

Under the conditions of this study, it seems that the addition of iodoform to the powder of Sealer 26 has influence on its physicochemical properties. Two properties are significantly altered: solubility and setting time. Only in the $24 \mathrm{~h}$ period, the addition of iodoform, in proportions of $1.1 \mathrm{~g}$ and $0.55 \mathrm{~g}$, decreased the $\mathrm{pH}$ value of the sealer. The flow and calcium release were not affected. Therefore, these alterations of the properties of Sealer 26 are likely to be clinically relevant, and these mixtures are not recommended for clinical use.

\section{REFERENCES}

1- Almeida JF, Gomes BP, Ferraz CC, Souza-Filho FJ, Zaia AA. Filling of artificial lateral canals and microleakage and flow of five endodontic sealers. Int Endod J. 2007;40:692-9.

2- American Society for Testing and Materials. ASTM C266-03: Standard test method for time and setting of hydraulic-cement paste by Gilmore needles. Philadelphia: ASTM; 2000.
3- Amorim LF, Toledo OA, Estrela CR, Decurcio DA, Estrela C. Antimicrobial analysis of different root canal filling pastes used in pediatric dentistry by two experimental methods. Braz Dent J. 2006;17:317-22.

4- Araki K, Hirakawa N, Kosugi T, Higashimoto I, Kakiuchi Y, Nakashima M. Iodoform intoxication: a case report of prolonged consciousness disturbance in a patient with a high plasma iodine level. Fukuoka Igaku Zasshi. 2007;98:397-401.

5- Aznar FD, Bueno CE, Nishiyama CK, Martin AS. Radiopacity of seven endodontic sealers evaluated using digitized radiograph. RGO. 2010;58:181-4.

6- Bodanezi A, Munhoz EA, Bernardineli N, Capelozza AL, Moraes IG, Bramante CM. Radiographic analysis of root canal fillings: influence of two sealers on the perception of voids. Braz Dent J. $2010 ; 21: 142-7$.

7-Camps J, Pommel L, Bukiet F, About I. Influence of the powder/ liquid ratio on the properties of zinc oxide-eugenol-based root canal sealers. Dent Mat. 2004;20:915-23.

8- Cerqueira DF, Mello-Moura AC, Santos EM, Guedes-Pinto AC. Cytotoxicity, histopathological, microbiological and clinical aspects of an endodontic iodoform-based paste used in pediatric dentistry: a review. J Clin Pediatr Dent. 2008;32:105-10.

9- Duarte MA, Demarchi AC, Giaxa MH, Kuga MC, Fraga SC, Souza LC. Evaluation of $\mathrm{pH}$ and calcium ion release of three root canal sealer. J Endod. 2000;26:389-90.

10- Duarte MA, El Kadre GD, Vivan RR, Tanomaru JMG, TanomaruFilho M, Moraes IG. Radiopacity of Portland cement associated with different radiopacifying agents. J Endod. 2009;35:737-40. 11- Duarte MA, Ordinola-Zapata R, Bernardes RA, Bramante CM, Bernardineli N, Garcia RB, et al. Influence of calcium hydroxide association on the physical properties of $\mathrm{AH}$ Plus. J Endod. 2010;36:1048-51.

12- Duarte MA, Weckwerth PH, Moares IG. Analysis of the antimicrobial action of sealers and pastes used in endodontic practice. Rev Odontol Univ São Paulo. 1997;11:299-305.

13- Estrela C, Pesce HF. Chemical analysis of the liberation of calcium hydroxyl ions from calcium hydroxide pastes in connective tissue in the dog - Part I. Braz Dent J. 1996;7:41-6. 14- Figueiredo JA, Vidor MM, Oliveira FF, Filipini HP, Gomes MS. Evaluation of the radiopacity of sealers called Sealapex and Sealer-26, with addition iodineform, by Accu-Ray digital image. Rev Fac Odontol Porto Alegre. 1997;38:11-8.

15- Gonçalves JL, Viapiana R, Miranda CE, Borges AH, CruzFilho AM. Evaluation of physico-chemical properties of Portland cements and MTA. Braz Oral Res. 2010;24:277-83.

16- Guerreiro-Tanomaru JM, Duarte MA, Gonçalves M, TanomaruFilho M. Radiopacity evaluation of root canal sealers containing calcium hydroxide and MTA. Braz Oral Res. 2009;23:119-23.

17- Holland R, Mello W, Souza V, Nery MJ, Bernabé PF, Otoboni Filho JA. Behaviour of the periapical tissues of dog's teeth to root canal filling with Sealapex with or without iodoform. Rev Odontol UNESP. 1990;19:97-104.

18- International Standardization Organization. ISO 6876: Dental root canal sealing materials. Geneva: ISO; 2001.

19- Mutoh N, Tani-Ishii N. A biocompatible model for evaluation of the responses of rat periapical tissue to a new zinc oxide-eugenol sealer. Dent Mater J. 2011;30:176-82.

20- Pizzo G, Giammanco GM, Cumbo E, Nicolosi G, Gallina G. In vitro antibacterial activity of endodontic sealers. J Dent. 2006;34:35-40.

21- Santos AD, Moraes JC, Araújo EB, Yukimitu K, Valério-Filho WV. Physico-chemical properties of MTA and a novel experimental cement. Int Endod J. 2005;38:443-7.

22- Sarigol CG, Cogulu D, Oncag O, Deliloglu IG. Cytotoxic effects of primary tooth root canal filling materials on L929 cell line. J Dent Child (Chic). 2010;77:72-6.

23- Silva LA, Leonardo MR, Oliveira DS, Silva RA, Queiroz AM, Hernández PG. Histopathological evaluation of root canal filling materials for primary teeth. Braz Dent J. 2010;21:38-45. 
24- Silva LA, Leonardo MR, Silva RS, Assed S, Guimarães LE. Calcium hydroxide root canal sealers: evaluation of $\mathrm{pH}$, calcium ion concentration and conductivity. Int Endod J. 1997;30:205-9. 25- Tanomaru JM, Cezare L, Gonçalves M, Tanomaru-Filho M. Evaluation of the radiopacity of root canal sealers by digitization of radiographic images. J App Oral Sci. 2004;12:355-7.

26- Tanomaru-Filho M, Saçaki JN, Faleiros FB, GuerreiroTanomaru JM. $\mathrm{pH}$ and calcium ion release evaluation of pure and calcium hydroxide-contained Epiphany for use in retrograde filling. J Appl Oral Sci. 2011;19:1-5.
27- Vivan RR, Zapata RO, Zeferino MA, Bramante CM, Bernardineli N, Garcia RB, et al. Evaluation of the physical and chemical properties of two commercial and three experimental root-end filling materials. Oral Surg Oral Med Oral Pathol Oral Radiol Endod. 2010;110:250-6.

28- Zhang H, Shen Y, Ruse ND, Haapasalo M. Antibacterial activity of endodontic sealers by modified direct contact test against Enterococcus faecalis. J Endod. 2009;35:1051-5. 